\title{
採血による血管迷走神経反応の 実態調查ならびにその対応について
}

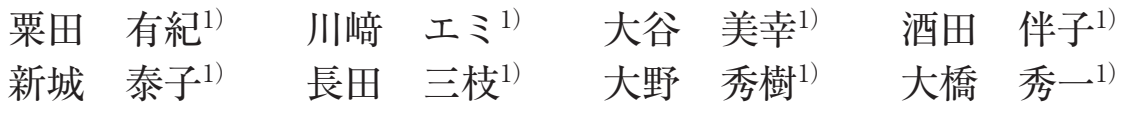

\section{抄 録}

【背景】血管迷走神経反応（vasovagal reaction: VVR）は、採血中や採血後に迷走神経興奮によって生じる諸 症状を総称する。血圧低下、徐脈、吐き気などを示し、重症の場合には、意識消失、痙攣、失禁にいたる。不安 や緊張によって起こりやすいと言われており、採血の副作用としては最も発生頻度が高いとされている。 【目的】健保連大阪中央病院健康管理センターにおける VVR の実態調査を行い、対応策を作成する。 【方法】2012年11月から2013年10月までの 1 年間に、総受診者55,150名中 VVR を発症した144名を対象とし て、発症率・性別・年齢・程度・採血体位・回復時間を調べた。程度の判定基準には厚生労働省の「血管迷走神 経反応による症状群の程度別分類」を用いた。さらに看護師20名の意識調査を行い、これらを総合的に検討した。 【結果】VVR 発症率は $0.26 \%$ 、男女比では女性が、年齢別では若年層が高(傾向となった。程度別では最も軽

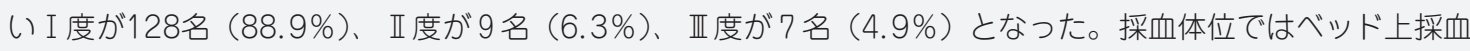
が全て I 度にとどまり、重症化を防いでいる事が分かった。回復時間は106名（73.6\%）が5 分以内に回復し、

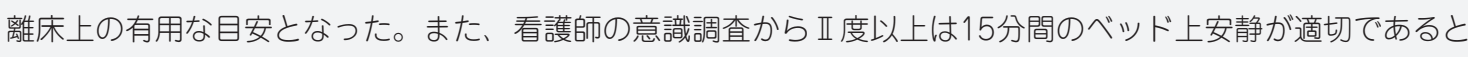
判断した。

【結語】健診での採血時 VVR は高頻度ではないが特に若年者、女性に注意することが重要である。また離床上 の目安としては 5 分每のバイタルサイン測定を織り込んだ「採血によるVVR 対応策」を作成することによって、 一定の安全対策が確立できた。

（総合健診. $2015 ； 42 ： 623-628$. )

キーワード＼cjkstart採血、血管迷走神経反応、回復時間、対応策

\section{ヤリはじめに}

血管迷走神経反応 (vasovagal reaction：以下 VVR）は、採血中や採血直後に、迷走神経興奮に よって生じる諸症状を総称する。血圧低下、徐脈、 気分不快、冷感、顔面蒼白、吐き気、あくびなどを 示し、重症の場合には、意識消失、けいれん、失禁 に至る。VVRは針の穿刺に伴う神経生理学的反応と されるが、不安や緊張によって起こりやすいともい われており、採血における副作用としては、最も発 生頻度が高い1) とされている。また自己血採血では 発症率が $0.4 \sim 1.34 \%^{2)}$ とされ、女性と若年層に多い という報告2, 3) もある。一方、健保連大阪中央病院 健康管理センター（以下当センター）では、年間約

〔論文受付日：2015年 6 月25日〕〔論文受理日：2015年 8 月21日〕

1 ) 健康保険組合連合会大阪中央病院健康管理センター
55,000 名が受診し、採血によるVVR の発症は 1 カ 月に10名程であるが、幸いこれまで転倒事故などの 重篤な事態は生じていない。しかし従来の対策は、 問診を行った後 VVR 経験者をベッド上採血に誘導 し、発症時には 2 名以上で安全を確保し、離床等の 判断は個々のスタッフに委ねられているのが現状で ある。

\section{$\longrightarrow$ 目 的}

そこでVVRに対する合理的な安全対策を確立す るために、当センターにおける過去 1 年間の VVR 発症者の実態調查を行い、その対応策を検討した。

\section{$\rightarrow$ 対 象}

2012年11月 1 日 2013年10月31日の 1 年間に当 
センターを受診した総受診者 55,150 人のうち VVR を発症した144名。および当センター看護師：20名 (平均年齢38.3歳、平均勤続年数 2.4 年)。

\section{方 法}

\section{（1）VVR 程度別の判定基準}

厚生労働省の「血管迷走神経反応による症状群の 程度別分類」4)を用いた（表 1 ）。

\section{（2）VVRの実態調査}

従来から日々の看護業務日誌には、VVR も含め 受診者に体調不良が生じた場合は、バイタルサイン （以下 VS）測定・症状を観察し、状況に応じて医師 への診察依頼を行い、転帰までの経過を記載してい たが、詳しい情報を得るために独自の「大阪中央病 院VVR 記録用紙」（図1) を作成した。調查項目

\section{表 1 血管迷走神経反応による症状群の程度別} 分類 (厚生労働省)

\begin{tabular}{|c|c|c|}
\hline & \multicolumn{2}{|c|}{ 症 状 } \\
\hline & 必須症状·所見 & Optional な症状 \\
\hline I 度 & $\begin{array}{l}\text { 血圧低下 } \\
\text { 徐脈 }(>40 / \text { 分 })\end{array}$ & $\begin{array}{l}\text { 顔面蒼白、冷汗 } \\
\text { 悪心などの症状を伴うもの }\end{array}$ \\
\hline II 度 & 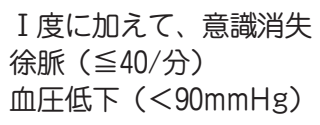 & 嘔吐、嘔気 \\
\hline III度 & $\begin{array}{l}\mathbb{I} \text { 度に加えて } \\
\text { 痙攣、失禁 }\end{array}$ & \\
\hline
\end{tabular}

注：正度には Optional な症状の記載なし

\section{図 1}

\section{大阪中央病院 VVR 記録用紙}

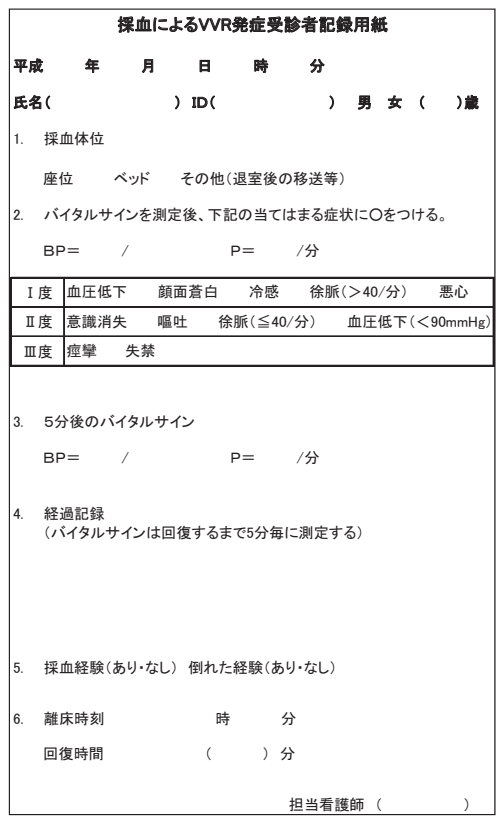

は、発症数 - 性別 - 年齢 - 症状の程度別分類 - 採血 体位・回復時間とした。また回復時間に関しては、 血圧はほほ 5 分で回復するという報告5) から、VS チェックは 5 分間隔と定めた。

\section{（3）看護師の意識調查}

実態調査期間中の 2013 年 7 月に、看護師の意識の 変化と離床目安時間について、無記名によるアン ケート調査を行った。

\section{（4）採血によるVVR 対応策を作成}

実態調查結果と看護師の意識調査及び意見をまと め、「採血による VVR 対応策」を作成した。

\section{$\gg$ 結 果}

\section{（1）発症率・男女別・年齢別について}

発症率は受診者数 55,150 名に対し発症者 144 名 （0.26\%）であった（表 2 )。男女別発症率は、男性 受診者数 32,482 名に対し発症者 82 名 $(0.25 \%)$ 、女 性受診者数 22,668 名に対し 62 名 $(0.27 \%)$ であった (表 3 )。年齢層からみた受診者数に対する発症者の 割合は、20歳以下 $(1.92 \%) 、 21 ３ 0$ 歳 $(0.69 \%)$ 、 $31 \sim 40$ 歳 $(0.35 \%) 、 41 \sim 50$ 歳 $(0.08 \%) 、 51 \sim 60$ 歳 $(0.02 \%) 、 61$ 歳以上 $(0.07 \%)$ であった（表 4$)$ 。

\section{(2) 症状の程度別分類について}

VVRによる症状群の程度別発症率の比較では、発 症者144名に対し、I 度128名 $(88.9 \%) 、$ II 度 9 名 (6.3\%)、正度 7 名 (4.9\%) であった（表 5 ）。

\section{（3）採血体位について}

発症者144名の内訳は、座位101名 (70.1\%)、ベッ ド上採血20名 $(13.9 \%) 、$ 採血室を退室した後に発 症したその他 23 名（16.0\%）であった。座位101名

\section{表 2 VVR 発症率}

\begin{tabular}{c|c}
\hline 受診者数 & 55,150 \\
\hline 発症数 & 144 \\
\hline 発症率 & $0.26 \%$ \\
\hline
\end{tabular}

\section{表 3}

VVR 男女別発症率

\begin{tabular}{c|c|c}
\hline \multirow{4}{*}{ 男 } & 受猃者数 & 32,482 \\
\cline { 2 - 3 } & 発症数 & 82 \\
\cline { 2 - 3 } & 発症率 & $0.25 \%$ \\
\hline \multirow{4}{*}{ 女 } & 受診者数 & 22,668 \\
\cline { 2 - 3 } & 発症数 & 62 \\
\cline { 2 - 3 } & 発症率 & $0.27 \%$ \\
\hline
\end{tabular}




\begin{tabular}{|c|c|c|c|c|c|}
\hline & \multicolumn{2}{|r|}{ 男 } & \multicolumn{2}{|r|}{ 女 } & \multirow{2}{*}{$\begin{array}{c}\text { VVR 発症者数 } \\
\text { 受診者数 } \\
\text { (割合) }\end{array}$} \\
\hline & 受診者数 & $\begin{array}{l}\text { VVR 発症者数 } \\
\text { (割合) }\end{array}$ & 受診者数 & $\begin{array}{l}\text { VVR 発症者数 } \\
\text { (割合) }\end{array}$ & \\
\hline 20歳以下 & 58 & $2(3.45 \%)$ & 46 & $0(\quad 0 \%)$ & $\begin{array}{c}2 / 104 \\
(1.92 \%)\end{array}$ \\
\hline $21 \sim 30$ 歳 & 4,843 & $35(0.72 \%)$ & 4,527 & $30(0.66 \%)$ & $\begin{array}{l}65 / 9,370 \\
(0.69 \%)\end{array}$ \\
\hline $31 \sim 40$ 歳 & 9,707 & $30(0.31 \%)$ & 7,232 & $29(0.40 \%)$ & $\begin{array}{c}59 / 16,939 \\
(0.35 \%)\end{array}$ \\
\hline $41 \sim 50$ 歳 & 9,250 & $12(0.13 \%)$ & 6,425 & $1(0.02 \%)$ & $\begin{array}{c}13 / 15,675 \\
(0.08 \%)\end{array}$ \\
\hline $51 \sim 60$ 歳 & 5,504 & $1(0.02 \%)$ & 3,029 & $1(0.03 \%)$ & $\begin{array}{l}2 / 8,533 \\
(0.02 \%)\end{array}$ \\
\hline 61 歳以上 & 3,120 & $2(0.06 \%)$ & 1,409 & $1(0.07 \%)$ & $\begin{array}{l}3 / 4,529 \\
(0.07 \%)\end{array}$ \\
\hline
\end{tabular}

\section{表 5 VVR 発症者（144名）の程度別割合}

\begin{tabular}{c|c|c}
\hline & 発症数 & 割合 \\
\hline I 度 & 128 & $88.9 \%$ \\
\hline II 度 & 9 & $6.3 \%$ \\
\hline II 度 & 7 & $4.9 \%$ \\
\hline
\end{tabular}

表 6 VVR 発症者（144名）の採血体位

\begin{tabular}{c|c|c|c}
\hline & 座位 & ベッド上 & $\begin{array}{c}\text { 关の他 } \\
\text { (退室後 VVR 発症) }\end{array}$ \\
\hline I 度 & $\begin{array}{c}85 \\
(59.0 \%)\end{array}$ & $\begin{array}{c}20 \\
(13.9 \%)\end{array}$ & $\begin{array}{c}23 \\
(16.0 \%)\end{array}$ \\
\hline II 度 & $\begin{array}{c}9 \\
(6.3 \%)\end{array}$ & 0 & 0 \\
\hline II 度 & $\begin{array}{c}7 \\
(4.9 \%)\end{array}$ & 0 & 0 \\
\hline 合計 & $\begin{array}{c}101 \\
(70.1 \%)\end{array}$ & $\begin{array}{c}20 \\
(13.9 \%)\end{array}$ & $\begin{array}{c}23 \\
(16.0 \%)\end{array}$ \\
\hline
\end{tabular}

の症状群の程度別分類は、 I 度85名 $(59.0 \%) 、$ II 度 9 名 (6.3\%)、正度 7 名 (4.9\%) であった。ベッ ド上採血20名とその他 23 名は、すべて I 度であった (表 6 )。

\section{（4）回復時間について}

発症者 144 名のうち、回復時間が 5 分以内 106 名 (73.6\%)、6～10分以内 15 名 (10.4\%)、11 15分以 内10名 (6.9\%)、16分以上 13 名 (9.0\%) であった。 症状群の程度別分類に押ける回復時間は、I 度は 5 分以内 95 名 $(66.0 \%) 、 6 \sim 10$ 分以内 15 名 (10.4\%)、 $11 \sim 15$ 分以内 8 名 $(5.6 \%) 、 16$ 分以上 10 名 $(6.9 \%)$ であった。II 度は 5 分以内 6 名 $(4.2 \%) 、 6 \sim 10$ 分 以内 0 名、11 15分以内 1 名 $(0.7 \%) 、 16$ 分以上 2
表 7 VVR 発症者（144名）の回復時間

\begin{tabular}{c|c|c|c|c}
\hline & 5 分以内 & $6 \sim 10$ 分以内 & 11 15分以内 & 16分以上 \\
\hline I 度 & $\begin{array}{c}95 \\
(66.0 \%)\end{array}$ & $\begin{array}{c}15 \\
(10.4 \%)\end{array}$ & $\begin{array}{c}8 \\
(5.6 \%)\end{array}$ & $\begin{array}{c}10 \\
(6.9 \%)\end{array}$ \\
\hline $\mathbb{I}$ 度 & $\begin{array}{c}6 \\
(4.2 \%)\end{array}$ & 0 & $\begin{array}{c}1 \\
(0.7 \%)\end{array}$ & $\begin{array}{c}2 \\
(1.4 \%)\end{array}$ \\
\hline II 度 & $\begin{array}{c}5 \\
(3.5 \%)\end{array}$ & 0 & $\begin{array}{c}1 \\
(0.7 \%)\end{array}$ & $\begin{array}{c}1 \\
(0.7 \%)\end{array}$ \\
\hline 合計 & $\begin{array}{c}106 \\
(73.6 \%)\end{array}$ & $\begin{array}{c}15 \\
(10.4 \%)\end{array}$ & $\begin{array}{c}10 \\
(6.9 \%)\end{array}$ & $\begin{array}{c}13 \\
(9.0 \%)\end{array}$ \\
\hline
\end{tabular}

名（1.4\%）であった。 III度は 5 分以内 5 名 $(3.5 \%) 、$ $6 \sim 10$ 分以内 0 名、11 15分以内 1 名 $(0.7 \%) 、 16$ 分以上 1 名 $(0.7 \%)$ であった。6 分以上でも、ほ とんどが15分以内で回復していたが、最長で I 度 55 分 (42歳・女性・月経中・ベッド採血・VVR 経験 あり) や、II度30分 (27歳・男性・椅子採血・VVR 経験なし)、III度45分（38歳・男性・椅子採血・ VVR 経験なし）の発症者がいた（表 7 ）。

\section{（5）看護師意識調査について}

アンケートを看護師 20 名に配布し回収率は $100 \%$ であった。

VVRについての意識の変化（複数回答可）につい ては、研究期間中に変化あり19名、なし 1 名であっ た。内容は、採血経験の少ない受診者や恐怖心の強 い受診者はべッド採血を勧めるようになった 18 名、 I 度の症状出現が分かるようになった13名、採血困 難な場合ベッドを使用した11名であった（表 8 ）。

VVR 発症後の回復時間調査で、離床目安時間の 5 分については、I 度は長い 0 名、適切 19 名、短い 1 名であった。複数回答で、適切な理由は、症状が 
消失している16名、VS が安定している 8 名であっ た。II 度は長い 0 名、適切 4 名、短い 10 名、分から ない 6 名であった。短い理由は、VS が安定しない 2 名、VS は安定するが自覚症状がある 7 名であっ た。III度は長い 0 名、適切 2 名、短い14名、分から ない 4 名であった。短い理由は、VS が安定しない 4 名、VS は安定するが自覚症状がある10名であっ た（表 9 )。

\section{表 8 VVRについて意識の変化（看護師意識調} 査)

$（ n=20$ 回収率100\%）

\begin{tabular}{c|c|c}
\hline & 人数 & \multicolumn{1}{c}{ 内容（複数回答） } \\
\hline あり & 19 & $\begin{array}{l}\text { ・採血経験の少ない受診者、恐怖心の強い受診者 } \\
\text { はベッド上採血を勧めた (18名) } \\
\text { ・度の症状出現が分かるようになった (13名) } \\
\text { ・採血困難な場合べッドを使用した }(11 \text { 名 })\end{array}$ \\
\hline なし & 1 & ・もともとVVR の知識があった (1 名)
\end{tabular}

\section{（6）「採血による VVR 対応策」について}

今回の調査を基に「採血による VVR 対応策」を 作成した。採血前には従来と同様に、当センターの 受診者記録と直前の口頭問診によるVVR 既往の確 認を行った。採血中はVVR 症状を見逃さないよう 観察項目を明記した。発症後の対応は看護師意識調 査結果から、I 度は回復時間 5 分で適切との意見が 大半を占めており、5 分毎に VS 測定を実施するこ とにした。また収縮期血圧 $90 \mathrm{mmHg}$ 以上、脈拍 40 回／分以上を離床の基準とした。II 度以上は回復時 間 5 分では短いと感じた看護師が大半であることか ら、原則15分以上のベッド上安静とし、血圧と脈拍 は I 度と同じ数值基準で、自覚・他覚症状の消失を もって離床可能とした。事後処理として発症者の情 報は次回の採血時、事前に確認出来るよう受診者記 録をシステムに入力しておくことで情報の共有化を 図った（表10）。

\section{表 9 離床目安時間 5 分について（看護師意識調査）}

$（ n=20$ 回収率100\%）

\begin{tabular}{|c|c|c|c|c|c|}
\hline & & 長() & 適切 & 短 & 分からない \\
\hline \multirow[b]{2}{*}{$\mathrm{I}$ 度 } & 人数 & 0 & 19 & 1 & 0 \\
\hline & 理由 & & 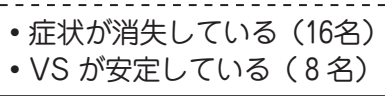 & • 理由記入なし（1 名） & \\
\hline \multirow[b]{2}{*}{ II 度 } & 人数 & 0 & 4 & 10 & 6 \\
\hline & 理由 & & 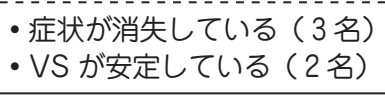 & 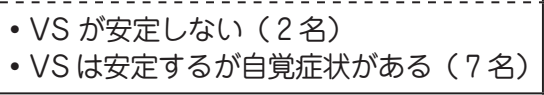 & \\
\hline \multirow[b]{2}{*}{ III度 } & 人数 & 0 & 2 & 14 & 4 \\
\hline & 理由 & & 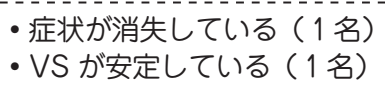 & •VS が安定しない（４名） & \\
\hline
\end{tabular}

注：理由は複数回答

\section{表10＼cjkstart採血による VVR 対応策}

\begin{tabular}{|c|c|c|c|c|c|}
\hline \multirow{2}{*}{ 採血前 } & 業務前確認 & \multicolumn{4}{|c|}{ 受診者記録にて前回の VVR 歴確認 } \\
\hline & 直前の口頭問診 & \multicolumn{4}{|c|}{$\begin{array}{l}\text { VVR 既往を確認 } \\
\text { (1) VVR 経験の有無 } \\
\text { (2) VVR 経験ありの場合、ベッド上採血を実施 } \\
\text { (3)採血室に必ず1名フリー看護師がいることを確認し、採血を実施 }\end{array}$} \\
\hline \multirow[b]{2}{*}{ 採血中確認事項 } & \multirow[b]{2}{*}{$\begin{array}{c}\text { VVR 判定基準 } \\
\text { 及び症状 }\end{array}$} & & I 度 & $\mathbb{I}$ 度 & III度 \\
\hline & & 症状 & $\begin{array}{l}\text { 血圧低下 } \\
\text { 徐脈 }(>40 / \text { 分 }) \\
\text { 顔面蒼白、冷汗、悪心等 }\end{array}$ & $\begin{array}{l}\text { I 度に加え } \\
\text { 意識消失、徐脈 }(\leqq 40 / \text { 分 }) 、 \\
\text { 血圧低下 }(<90 \mathrm{mmHg}) 、 \text { 嘔気・嘔吐 }\end{array}$ & $\begin{array}{l}\text { II 度に加え } \\
\text { 痙攣・失禁 }\end{array}$ \\
\hline $\begin{array}{c}\text { 発症後の対応策及び } \\
\text { 離床基準 }\end{array}$ & \multicolumn{5}{|c|}{ 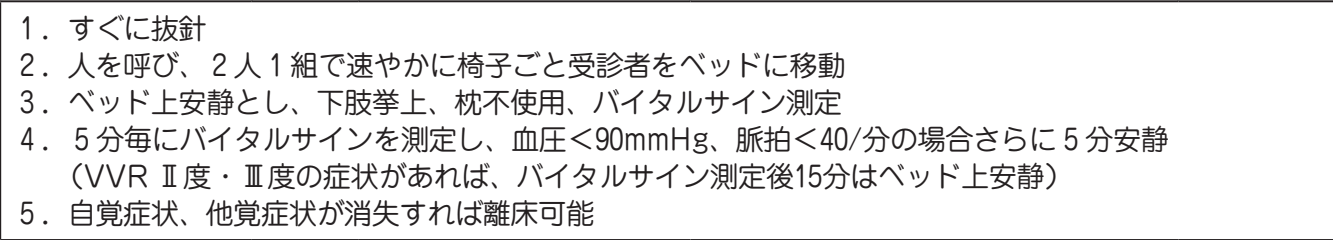 } \\
\hline 発症後の事後処理 & \multicolumn{5}{|c|}{ VVR 発症状況について受診者記録に入力しておく } \\
\hline
\end{tabular}




\section{考察}

当センターの VVR 発症率は、調査した 1 年間に おいて $0.26 \%$ であった。大八木ら ${ }^{2)}$ の報告で自己血 採血（採血椅子による採血と記載あり）による発症 率が $0.4 \%$ 1.34\%というものがあったが一般採血に よるVVR 発症率の報告は見当たらず比較すること は出来なかった。

男女別は、女性がVVRを起こしやすいとの報 告2,3) があったが、当センターでもわずかに女性の 割合が高いことが示された。

年齢別では、若年層にVVR が起こりやすいとの 報告 ${ }^{2}$ 3) がある。健診は主として就労年齢層が受診 しているため単純比較は難しく、当センターでも各 年齢層の男女別の発症を比較するにはデー夕数が少 なかったが、全体としては40歳までの若年層に発症 者が多いことが分かった。

症状群の程度別分類では、最も軽い I 度が 9 割近 くを占め、大半が軽症であった。頻度の少ない II 度・III度の症状を起こした受診者は、事前の口頭問 診から予測が出来るとは限らなかった。また我々独 自の VVR 記録用紙からも、II 度・III度の発生要因 について明らかなものは見出せなかった。

採血体位調查では、問診の際 VVR 経験なしで通 常の座位採血を行い発症した人は、発症者全体の 7 割で、程度別分類では I 度から III 度の全てのレベル を呈した。VVR経験ありや風邪や睡眠不足等体調不 良、採血に対する著明な緊張や不安を示す言動があ る場合、看護師の判断で、予めベッド上採血を行っ た20名は全て I 度でとどまり、II 度・III度への進行 はみられなかった。看護師意識調査では、問診の結 果予めベッド上採血を実施する看護師が増えてい た。看護師が適切な判断を行った結果、発症者の大 半が I 度でとどまったのではないかと考えている。

回復時間調査では、 5 分以内 6 分以上共に 8 割 以上が I 度と軽症であったが、I 度でも16分以上の 症例が10名（6.9\%）いたことから、症状の程度と回 復時間に関連性はみられなかった。

\section{$\gg$ まとめ}

今回の調查を基に「採血によるVVR 対応策」を 作成した。このことにより、看護師の経験年数に関 わらず、同じ対応がとれる体制が整った。また、表 形式とし採血室に揭示したことで、いつでもスタッ フが対応策を再確認出来るようになり、意識も高 まった。離床基準については回復時間調査の結果か ら、当センターにおいても発症後の離床は 5 分が目 安となることが確認出来た。但し、症状が軽くても 回復に時間を要する受診者もいたため、個別の観察 は重要である。今後も、作成した「採血によるVVR 対応策」を活かし、安心で安全な健診サービスを提 供していきたい。

\section{$\gg$ 結 論}

1. 看護師の口頭問診は、VVR 悪化の予防に繋がっ ている。

2. 回復時間として 5 分の安静は、離床の有用な目 安となった。

3.「採血によるVVR 対応策」によって、一定の安 全対策が確立できた。

著者の COI（conflict of interest）開示 : 本論文発表内容 に関連して特に申告なし

\section{$\longrightarrow$ 参考文献}

1) 大久保昭行: 別巻臨床検查. 系統看護学講座, 東京, 医 学書院, 2009; 42-3.

2) 大八木陽子, 高橋真木, 下平滋隆：自己血採血時におけ る VVR 防止のための看護師の役割. 信州大医病看研録 2007; 36: 71-5.

3) 堀内香与, 召田ひろみ, 下村陽子, 他: 自己血採血看護 手順書の作成に向けたVVR の分析. 信州大医病看研録 2008; 37: 93-5.

4) 厚生省血液研究事業 : 供血者保護のための採血基準設定 に関する研究. 昭和 59 年度研究報告書, $1985 ; 56-64$.

5) 飯沼紀子 : 自己血採血患者の供血反応予防の援助採血後 に重点を执いて。信州大医病看研録 1995; 25: 55-62. 


\title{
Strategy for the precaution of vasovagal reactions (VVRs) during blood sampling in our healthcare center
}

\author{
Yuki Awata' ${ }^{1)}$ Emi Kawasaki ${ }^{1)}$, Miyuki Ohtani ${ }^{1)}$, Tomoko Sakata1), Yasuko Shinjo ${ }^{1)}$, \\ Mie Nagata' ${ }^{1)}$, Hideki Ohno' ${ }^{1}$, Shuichi Ohashi ${ }^{1{ }^{\prime}}$ \\ 1) Osaka Central Hospital Healthcare Center
}

BACKGROUND: Vasovagal reaction (VVR) is an adverse event such as drop in blood pressure, bradycardia, and nausea occurring during or after blood sampling. VVR is one of the well-known reactions during blood sampling, and it could lead to faintness, convulsion, and incontinence. In serious cases; however, few papers have been published regarding VVRs at medical examination. We aimed to investigate the characteristics of VVRs and propose a precaution manual during blood sampling.

METHODS: We extracted 144 cases with VVRs out of 55,150 examinees seen in Osaka Central Hospital Healthcare Center from November 2012 until October 2013. We retrospectively analyzed age, sex, severity of VVRs, posture during blood sampling and recovery time. A questionnaire survey about VVR was performed among 20 nurses and their opinions were reflected in the precaution manual during blood sampling.

RESULTS: Female showed the higher rate of VVRs (male:0.25\% v.s. female:0.27\%) among 55, 150 examinees. From 144 cases with VVRs, the younger generation showed high tendency (age $\leqq 40$ yrs: $87.5 \%$ v.s. age $\geqq 41$ yrs: $12.5 \%$ ). Regarding the severity of WVRs, 128 cases were mild (88.9\%: Grade I); 9 cases were moderate (6.3\%: Grade II), and 7 were severe (4.9\%: Grade III). All 20 examinees collected in supine position remained Grade I, suggesting the usefulness of supine position. Of note, 106 examinees (73.6\%) recovered within five minutes, which could be a criterion for recovery of VVRs. From the questionnaire survey, most nurses agreed that more than 15 minutes of supine posture is needed to relieve Grade II and III VVRs. A precaution manual for blood sampling to avoid VVR is proposed, which includes a questionnaire for examinees and routine checking of vitals every five minutes to alert medical staff.

CONCLUSION: At medical examination, WVRs are not frequent side effects during blood sampling, but examinees, especially who are young and female, should be treated more carefully using our precaution manual.

(HEP. 2015;42:623-628.)

\section{KEY WORDS}

blood sampling, vasovagal reaction (VVR), recovery time, precaution manual 